\title{
HARMONI DALAM “?”: SEBUAH INTERAKSI SOSIAL MASYARAKAT MULTIKULTURAL
}

\author{
Septiawan Setiarsa \\ MA AL-ISlamiyah 1 Sumberbatu Pamekasan \\ awansetiarsa@gmail.com
}

ABSTRAK

Tujuan penelitian ini untuk mengetahui bentuk 1.) Interaksi sosial asosiatif dan 2.) Interaksi sosial disosiatif dalam novel Harmoni dalam "?" karya Melvy Yendra dan Andriyati. Jenis penelitian ini adalah penelitian kualitatif yaitu penelitian yang bertujuan untuk memahami fenomena atau gejala yang dialami oleh subjek penelitian. Metode yang digunakan dalam penelitian ini adalah metode deskripsi. Metode deskripsi adalah metode yang menggambarkan atau melukiskan fakta-fakta atau gejala secara sistematis. Hasil analisis data tentang interaksi sosial asosiatif dan interaksi sosial disosiatif dalam novel Harmoni dalam “?” karya Melvy Yendra dan Andriyati berwujud 1.) Interaksi sosial asosiatif bentuk kerja sama antara atasan dengan bawahan, kerja sama dalam kegiatan keagamaan, dan kerja sama dalam kegiatan kemanusiaan. Akomodasi dalam bentuk toleransi yaitu kebebasan dalam menjalankan ibadah, menghormati ajaran dan eksistensi agama lain, kebebasan dalam memeluk agama, dan bebas dalam berpikir. 2.) Interaksi sosial disosiatif bentuk persaingan dalam percintaan. Kontravensi dalam bentuk penolakan, memfitnah, provokasi dan intimidasi. Konflik yang terjadi atas dasar rasisme yang mengakibatkan perkelahian.

Kata Kunci : Interaksi Sosial, Multikultural, Asosiatif, Disosiatif

ABSTRACT

The purpose of this research is to find in form of : 1.) Interaction of social association, and 2.) Interaction of social dissociation in the novel Harmoni dalam "?" written by Melvy Yendra and Andriyati. This research was conducted in qualitative research aimed to understand the phenomenon or symptoms experienced by the subject of research. The method used in this study was description. Description method is a method that describes the facts or symptoms systematic. The result of data analysis of the social associative interaction and social dissociative interaction in the novel Harmoni dalam "?" written by Melvy Yendra and Andriyati were 1.) Social associative interaction in form of cooperation between superiors and subordinate, cooperation in religious activity, and cooperation in humanity activity. Accommodation in the form of tolerance was freedom in worship, respect for the teachings and the existence of other religions, freedom of religion, and freedom of thinking. 2.) Social dissociative interaction was in the form of competition in romance. Contravention was in the form of rejection, defamatory, 
provocation and intimidation. Conflict occurred in the basis of racism leads to a fight.

Keywords : Social, Multicultural, Associative, Dissociative Interaction

PENDAHULUAN
Keragaman merupakan salah satu keistimewaan yang dimiliki negara Indonesia. Keragaman yang ada berupa ragam suku, budaya, bahasa, religi, kesenian, adat istiadat ataupun kebiasaan. Masyarakat dengan berbagai kompleksitas keragaman seperti di Indonesia dikenal dengan istilah masyarakat multikultural. Konflik yang terjadi di Indonesia menunjukkan bahwa tidak selamanya proses interaksi menghasilkan hal yang positif. Seringkali muncul masalah sosial dalam interaksi yang disebabkan adanya perbedaan. Kenyataan tersebut menguatkan pernyataan bahwa proses interaksi bisa mengarah pada hal yang bersifat negatif. Hal itu sesuai dengan pernyataan Gillin dan Gillin (dalam Soekanto, 2007:64) yang mengadakan penggolongan mengenai interaksi sosial menjadi dua bentuk, yaitu asosiatif dan disosiatif. Interaksi asosiatif merupakan proses interaksi yang mengarah atau menghasilkan hal yang positif, sedangkan interaksi disosiatif merupakan proses interaksi yang mengarah atau menghasilkan hal yang negatif.

Realitas masyarakat Indonesia sesungguhnya telah banyak dicitrakan pada berbagai media. Salah satunya dalam bentuk karya sastra. Karya sastra sebagai sebuah kreativitas mencoba mengungkapkan perilaku manusia dalam kehidupannya. Karya sastra dapat menjadi sebuah ensiklopedi sosial mini yang memberikan banyak informasi bagi pembaca tentang sebuah struktur dan kehidupan sosial masyarakat tertentu.

Novel berjudul Harmoni dalam "?" merupakan salah satu karya sastra yang menjadi potret miniatur multikultural di Indonesia. Novel ini merupakan bentuk novelisasi dari film “?” karya Hanung Bramantyo. Berkisah tentang dinamika kehidupan beberapa tokoh yang semuanya berbeda latar belakang budaya, status, agama, etnis dan tingkat sosial ekonomi. Penulis tertarik untuk meneliti novel Harmoni dalam “?” karya Melvy Yendra dan Andriyati karena dalam novel tersebut diperoleh gambaran mengenai interaksi sosial masyarakat multikultural yang hidup berdampingan dan penuh dengan perbedaan. Novel Harmoni dalam “?” menjadi sebuah refleksi tentang kehidupan masyarakat Indonesia saat ini. Bentuk toleransi mendapat perhatian khusus dan menjadi pengembangan dalam penelitian ini.

Hal itu didukung oleh penelitian yang dilakukan oleh Lande (2014) menunjukkan bahwa makna yang disampaikan dalam film “?” adalah toleransi antar umat beragama merupakan jawaban atas penyelesaian konflik agama yang terjadi di masyarakat. Penelitian yang dilakukan oleh Khasanah (2016) menemukan bahwa nilai toleransi yang terdapat dalam film “?” berupa nilai toleransi agama seperti menghormati ibadah agama lain dan melaksanakan ibadah sesuai ajaran agama dan nilai toleransi sosial berbentuk saling 
METODE

\section{PEMBAHASAN}

menjaga keamanan rumah ibadah antar umat beragama dan menjalin kerja sama dengan pemeluk agama lain.

Metode yang digunakan dalam penelitian ini adalah metode deskripsi kualitatif. Metode deskripsi kualitatif adalah metode yang menggambarkan atau melukiskan fakta-fakta atau gejala secara sistematis melalui pengamatan, wawancara, atau penelaahan dokumen. Data dalam penelitian ini merupakan data kualitatif, dengan kata lain data yang dikumpulkan dalam penelitian kualitatif deskriptif berupa kata-kata bukan berupa angka-angka. Wujud data dalam penelitian ini berupa kata-kata, kalimat, dan dialog yang terdapat dalam Novel Harmoni dalam “?” karya Melvy Yendra dan Andriyati.

Data dikumpulkan dengan teknik dokumentasi dan antologis. Teknik dokumentasi digunakan karena sumber data disikapi sebagai dokumen atau sebagai dokumen pribadi tertulis. Teknik antologis digunakan dalam penelitian ini untuk mengumpulkan data dan mengelompokkan data berdasarkan fokus kajian. Data akan berupa kutipan-kutipan dari novel Harmoni dalam “?” karya Melvy Yendra dan Andriyati.

\section{Interaksi Sosial Asosiatif} Kerja Sama (Cooperation)

Berikut data yang ditemukan sehubungan dengan bentuk kerja sama pada novel Harmoni dalam “?”.

Tuhan menjatuhkan takdirnya pada hari itu untuk Fatimah. Wanita itu datang saat Koh Tan baru saja ditinggal pergi salah seorang karyawannya yang pindah ke luar kota. Tapi ada sedikit keraguan di hati Tan Kat Sun untuk menerima Fatimah karena Fatimah adalah seorang muslim. Apakah ia mau bekerja di restorannya yang juga menjual aneka masakan Indonesia dan juga masakan Cina yang khas?. (Hd?/KS/YdA/2011/hlm 30)

Awal mula proses kerja sama antara Koh Tan dengan Fatimah terjadi ketika Fatimah sedang mencari pekerjaan sampai akhirnya bertemu dengan Koh Tan yang memiliki sebuah restoran. Koh Tan yang beragama Konghucu bersedia menolong Fatimah dengan menjadikannya pegawai. Hal itu membuktikan bahwa kerja sama dapat terjadi melalui sikap tolong menolong. Saling tolong menolong dapat dilakukan tanpa memandang agama, suku, ras maupun etnis. Perbedaan yang ada tidak bisa membatasi terjadinya kerja sama.

Soal pekerjaan, Koh Tan pun membagi karyawannya menjadi dua bagian. Satu kelompok yang mengolah dan menghidangkan masakan cina dari babi. Mereka ada tiga orang, semuanya dari etnis Tionghoa. Kelompok kedua yang mengolah dan menghidangkan masakan yang halal, ada empat orang termasuk Fatimah. (Hd?/KS/YdA/2011/hlm 40) 
Pada kutipan di atas, pembagian kelompok yang dilakukan oleh Koh Tan tentu sangat bijaksana dan tepat. Karyawan yang bekerja di restoran itu bukan hanya terdiri dari etnis Tionghoa saja tapi, juga terdapat karyawan lain yang beragama Islam. Mengingat bahwa dalam agama Islam dilarang bersentuhan dengan babi yang dianggap haram. Pembagian tugas tersebut menempatkan mereka pada tugas dan tanggung jawab sesuai dengan keyakinan masingmasing.

“Eh, Menuk, apa kabar?” tanya Romo.

“Baik, Romo. Ada yang bisa saya bantu, Romo?” tanya Menuk ramah.

"Iya, besok malam kan perayaan paskah. Jadi, seperti biasa, gereja

Maupesan konsumsi untuk jemaat,” kata Romo.

“Oh, iya, baik Romo,” kata Menuk. ”Berapa banyak Romo?”

"Ya, samain saja seperti yang sudah-sudah," kata Romo lalu mengeluarkan amplop berisi uang. "Ini uang mukanya. Sisanya nanti dibayar sama anak-anak. Oh, ya, salam buat Koh Tan. Sibuk sekali tampaknya," katanya tertawa. (Hd?/KS/YdA/2011/hlm 248)

Kutipan di atas menunjukkan bahwa interaksi mutlak diperlukan dalam masyarakat multikultural. Interaksi yang terjalin membentuk hubungan kerja sama menunjukkan bahwa manusia merupakan makhluk sosial dan membutuhkan orang lain. Hal itu ditunjukkan oleh tindakan Romo Djiwo yang selalu memesan konsumsi jemaat dalam perayaan keagamaan pada restoran Koh Tan. Perbedaan agama antara Koh Tan dan Romo Djiwo tidak menghalangi mereka untuk melakukan kerja sama demi memenuhi kebutuhan mereka.

Dari kejauhan melangkah mendekat sepasang suami istri membawa

kantung yang cukup besar. Rika berdiri.

"Itu mereka," kata Rika.

Surya si "Santa Clause" ikut berdiri.

"Maaf menunggu," kata si suami yang bernama Alex.

“Gapapa, mas. Kenalkan, ini Surya, kata Rika.

"Halo, mas Surya. Makasih ya sudah mau jadi Santa," kata Melanie, istrinya. Suami istri itu menyalami Surya. Melanie lalu menunjukkan kantungnya. "Mas Surya bawa ini ke dalam serahkan ke Abi,” katanya. (Hd?/KS/YdA/2011/hlm 287-288)

Kutipan di atas menunjukkan hubungan yang berbeda agama tapi tidak menghalangi mereka untuk saling membantu. Alex dan Melanie yang merupakan orang tua Abi meminta kepada Surya untuk berperan sebagai Santa Clause dan memberikan hadiah 
kepada anaknya yang sedang sekarat di rumah sakit. Santa Clause dipilih karena itu merupakan tokoh favorit Abi. Surya yang berprofesi sebagai seorang aktor tentunya dengan mudah bisa memerankannya.

\section{Akomodasi (Accomodation) Bentuk Toleransi}

Dalam penelitian ini ditemukan beberapa bentuk akomodasi toleransi sebagai berikut:

Saya akan bekerja dengan sangat hati-hati, Koh,” katanya. Biarlah itu menjadi urusan dan tanggung jawab saya kepada Tuhan.” Sambung Fatimah. Koh Tan menerima janji Fatimah itu, ia juga akan sangat menghormati segala hak Fatimah sebagai seorang muslim, sebagaimana ia lakukan kepada tiga pegawai muslim lainnya yang saat ini bekerja padanya (Hd?/Ako/T/MHS/YdA/2011/hlm 31).

Bentuk pengakuan hak oleh Koh Tan terhadap Fatimah dan pegawainya yang lain adalah dengan memberikan cuti lebaran, dan memisahkan antara karyawan yang muslim dengan non muslim dalam hal pekerjaan. Pemisahan dilakukan karena di restoran tersebut juga menjual makanan babi dan dikhawatirkan para karyawan muslim bersinggungan dengan hal yang haram dalam agamanya. Mereka juga punya hak untuk menganut agama dan kepercayaan yang diyakininya.

"Ya saya akan pikir-pikir dulu dan Tanya Pak Ustadz boleh apa nggak,"

"Nah, gitu dong. Beri diri kamu setidaknya kesempatan untuk memilih!” kata Rika lagi. (Hd?/Ako/T/MHS/YdA/2011/hlm 225)

Kesulitan pekerjaan yang dialami Surya akhirnya didengar oleh Rika. Rika berusaha membantu dengan menawarkan peran Yesus dalam acara Paskah. Surya yang merasa ragu dengan pekerjaan tersebut mempertimbangkan dan ingin bertanya kepada ustadz Wahyu mengenai pekerjaan yang ditawarkan Rika untuk casting menjadi peran Yesus. Surya merasa ragu dengan pekerjaan yang ditawarkan oleh Rika karena hal itu bertentangan dengan keyakinannya, sehingga dia memutuskan untuk bertanya kepada ustadz Wahyu mengenai keputusannya tersebut.

"Gini, Leh. Kamu tau kan soal rangkaian bom gereja yang dilancarkan teroris? Atau penusukan pastur yang terjadi di gereja lain yang sekarang beritanya lagi ramai di televisi, kamu juga nonton kan?” Soleh mengangguk.

"Berita itu membuat pandangan orang sama Islam jadi jelek. Nah, kita sebagai salah satu ormas Islam terbesar menolak pandangan itu dengan cara seperti ini. Menurut kita, pengabdian sebagai Banser ini juga salah satu jihad, Leh...," (Hd?/Ako/T/MHS/YdA/2011/hlm 255) 
Sikap toleransi dari Banser NU merupakan bentuk toleransi mengakui hak yang dimiliki oleh setiap orang. Komandan Banser itu tidak setuju dengan adanya diskriminasi dan ancaman terhadap penganut agama lain berupa penusukan pastur dan ancaman dalam kegiatan ibadah serta aksi pengeboman gereja yang sedang marak terjadi sehingga mengakibatkan Islam menjadi buruk di mata masyarakat. Banser NU mengadakan pengamanan di luar gereja sebagai bentuk sikap menghormati hak setiap orang yaitu bebas memeluk agama dan beribadat sesuai agamanya.

Mereka diberi cuti lebaran lima hari, agar bisa berkumpul bersama keluarga, dan tradisi itu dipertahankan oleh Koh Tan selama bertahun-tahun. Karyawan yang muslim pun tak dilarang untuk izin shalat di masjid atau pergi shalat Jumat buat yang laki-laki. (Hd?/Ako/T/MKO/YdA/ 2011/hlm 3940)."

Ketika bekerja pada Koh Tan, Fatimah mendengar cerita dari pekerja lainnya mengenai kebaikan Koh Tan yaitu pemberian cuti lebaran selama lima hari supaya para pekerja bisa berkumpul dengan keluarganya selama lebaran. Sikap itu menunjukkan kebebasan yang diberikan Koh Tan untuk merayakan hari besar agama. Koh Tan juga memberikan kesempatan kepada pegawai laki-laki untuk melaksanakan shalat Jumat di masjid. Hal itu juga menunjukkan Koh Tan menghormati keyakinan orang lain dalam menjalankan ibadahnya baik secara pribadi maupun bersama-sama, baik secara tertutup maupun terbuka.

Soal pekerjaan, Koh Tan pun membagi karyawannya menjadi dua bagian. Satu kelompok yang mengolah dan menghidangkan masakan cina dari babi. Mereka ada tiga orang, semuanya dari etnis Tionghoa. Kelompok kedua yang mengolah dan menghidangkan masakan yang halal, ada empat orang termasuk Fatimah. Peralatan masak dan piring-piring yang digunakan juga dibedakan antara makanan olahan babi dan makanan halal. (Hd?/Ako/T/MKO/YdA/2011/hlm 40).

Sikap Koh Tan yang membagi karyawannya menjadi dua bagian kelompok menunjukkan bahwa dia menghormati keyakinan orang lain. Kelompok pertama yang merupakan pegawai dari etnis Tionghoa, bertugas untuk mengolah dan menghidangkan masakan cina dari babi. Kelompok kedua berjumlah empat orang termasuk Fatimah bertugas mengolah dan menghidangkan masakan yang halal. Peralatan memasak dan piring-piring yang digunakan juga dibedakan antara makanan olahan babi dan makanan halal. Sikap Koh Tan menunjukkan bahwa dia menghormati keyakinan dan keragaman ajaran-ajaran agama lain.

"Jangan lupa semua jendela ditutup pake tirai.....Jangan jualan babi juga selama sebulan. Kita harus ngehormatin yang puasa. Paham kamu, Hen?” kata Koh Tan. (Hd?/Ako/T/MKO/YdA/2011/hlm 273) 
Koh Tan mengingatkan Hendra mengenai beberapa hal dan ketentuan selama bulan puasa yang selama bertahun-tahun menjadi tradisi di restoran itu yaitu untuk menutup jendela menggunakan tirai dan tidak berjualan babi selama bulan puasa untuk menghormati orang yang sedang berpuasa. Sikap itu menunjukkan bahwa Koh Tan menghormati keyakinan orang lain di bulan puasa yang sedang menjalankan ibadah puasa supaya ibadah mereka tidak terganggu.

\section{Interaksi Sosial Disosiatif \\ Persaingan (Competition)}

Berikut ini akan dijelaskan kutipan yang berhubungan dengan pertentangan:

Menuk menyadari apa yang menyebabkan Hendra bersikap seperti itu terhadapnya. Sikap acuh dan tak peduli, bahkan sesekali memandang dengan tatapan marah itu bermula sejak Hendra mendengar rencana pernikahan Menuk dengan Soleh. Dan Hendra tidak mampu mencegahnya. (Hd?/P/Pri/YdA/ 2011/hlm 118)

Kutipan di atas menunjukkan awal mula persaingan yang terjadi antara Soleh dengan Hendra. Keduanya sama-sama tertarik pada Menuk untuk dijadikan sebagai kekasih. Persaingan itu terhalang oleh adanya perbedaan agama diantara mereka dan menyebabkan Menuk lebih memilih Soleh daripada Hendra untuk dijadikan sebagai suami. Fatimah yang merupakan ibu Menuk tidak setuju jika Menuk berhubungan dengan Hendra. Hal itu dibuktikan melalui kutipan di bawah:

Dua hari sebelum Menuk berangkat ke Yogya, Hendra pulang. Ia mendapat kabar Menuk mau menikah dari ibunya. Hendra terkejut. Kaget bukan kepalang. Ia merasa selama ini Menuk mencintai ia. Tapi Menuk tidak pernah berani mengungkapkan isi hatinya. Atau Menuk takut pada ibunya yang mungkin tidak setuju anaknya punya pacar orang Cina dan berbeda agama pula. (Hd?/P/Pri/YdA/2011/hlm 119)

Hendra sangat marah ketika mendengar pernikahan antara Soleh dengan Menuk dan membuat Hendra merasa sakit hati. Hendra merasa selama ini Menuk lebih mencintai dia daripada Soleh. Menuk hanya tidak mau mengatakan cinta padanya. Hendra menduga Menuk menolak cintanya karena ibunya tidak setuju dengan adanya perbedaan agama antara mereka.

Dari arah gedung di samping gereja yang merupakan sekretariat paroki, Surya melangkah mendekat. Rika berdiri.

“Itu temenku. Dah, Doni."

Doni tak menyahut. Ia memerhatikan Rika dan Surya sambil melangkah ke mobilnya. Doni yang duduk di dalam mobilnya, menatap keakraban kedua orang itu dengan dada sakit. (Hd?/P/Pri/YdA/2011/hlm 243-244) 
Persaingan untuk mendapatkan cinta Rika terjadi antara Surya dengan Doni. Keduanya memiliki keinginan untuk bisa dekat dan menjadi kekasih Rika yang memiliki status janda setelah bercerai dengan suaminya. Ada satu kendala yang dihadapi oleh mereka, yaitu adanya perbedaan agama. Hal tersebut membuat persaingan mereka semakin panas. Doni yang beragama Kristen merasa bisa mendapatkan Rika yang memiliki kepercayaan yang sama dengannya. Namun sayangnya Rika lebih tertarik pada Surya yang beragama Islam.

\section{Kontravensi (Contravention)}

Beberapa bentuk kontravensi ditemukan dalam kutipan novel Harmoni dalam "?” yang akan dipaparkan dibawah ini:

“Apa tidak ada pekerjaan lain, Fat?'

Masakan Cina itu kan banyak memakai bumbu dan makanan haram menurut hukum agama kita. Apa kamu tidak khawatir?” kata Rahma, tidak bisa menepis rasa penyesalannya terhadap keputusan Fatimah. (Hd?/K/YdA/2011/hlm 31)

Sebagai sahabat Fatimah, Rahma merasa khawatir dengan pekerjaan yang dilakukan sahabatnya itu. Fatimah yang bekerja di restoran Koh Tan akan mudah sekali bersinggungan dengan masakan babi yang haram dalam agamanya. Rasa penyesalan timbul dalam diri Rahma.

Sejak mulai bekerja di restoran itu, tak sedikit ia menerima tatapan dan kata-kata sinis dari orang-orang disekitar, baik dari pekerja dari toko-toko sebelah di pasar itu, maupun dari para tetangga di kontrakan.

(Hd?/K/YdA/2011/hlm 41)

Sejak Fatimah bekerja direstoran Koh Tan, para tetangga memiliki pandangan yang berbeda karena Fatimah yang beragama Islam bekerja pada Koh Tan yang beragama Khonghucu. Hal itu disebabkan restoran tersebut juga menjual masakan dari babi. Pandangan sinis kerap diterima dari semua orang yang ada dalam lingkungannya.

Hendra mendengus kesal.

"Menuk itu tidak mencintai Soleh, Mi! Menuk memilih nikah sama Soleh hanya karena terikat janji sama ibunya!” katanya dengan berapi-api. "Dia memilih Soleh hanya karena menurutnya Soleh adalah laki-laki yang taat beragama. Taat tok!!!” (Hd?/K/YdA/2011/hlm 259-260)

Hendra merasa kesal dan Marah ketika dinasehati oleh maminya untuk melupakan Menuk dan tidak membenci Soleh. Hendra tidak suka terhadap hubungan Soleh dengan Menuk. Hendra berpikiran bahwa Menuk menikahi Soleh karena dia taat beragama dan bukan berlandaskan cinta. Itu yang membuat Hendra begitu membenci Soleh dan Menuk. 
"Nggak Cuma tirai yang dicopot, tapi kami juga gak dikasih waktu buat shalat lagi. Jadi harus nyolong-nyolong waktu buat shalat," kata Menuk. "Dasar Cina," makinya walau dengan suara pelan.

Menuk menoleh dengan cepat ke arah Soleh.

"Mas, ini aku lagi ngomongin Hendra, bukan ngomongin Cina,” protesnya. (Hd?/K/YdA/2011/hlm 285)

Soleh marah ketika mendengar bahwa para pekerja yang bekerja di restoran Koh Tan dipersulit untuk beribadah. Soleh memaki-maki Hendra dengan nada rasis. Tapi Menuk mengatakan bahwa dia sedang membicarakan Hendra, bukan berbicara tentang etnis Cina secara keseluruhan.

\section{Pertentangan (Conflict)}

Ditemukan beberapa kutipan mengenai pertentangan dalam novel Harmoni dalam “?” yang akan dipaparkan sebagai berikut:

Ketika berpapasan dengan Hendra, seorang pemuda melihat Hendra dengan sorot mata yang tajam. "Apa liat-liat koe?" bentak Hendra. Kelompok pemuda berbaju koko langsung ikut berhenti ketika mendengar kata-kata Hendra yang pedas. "Dasar sipit!!!" pemuda itu membalas emosi. "Apa koe bilang??? Dasar teroris!!!” Hendra membalas dengan nada ledakan emosi yang tidak mampu lagi terbendung. (Hd?/P/YdA/2011/hlm 125)

Ketika keluar dari gang rumahnya, Hendra bertemu dengan beberapa pemuda masjid. Terjadilah pertikaian yang diawali dengan munculnya kata-kata kasar dan bersifat rasis dari para pemuda masjid. Kata-kata rasis tersebut membuat Hendra marah dan menyebut mereka semua teroris.

"Jadi, yang kayak gini ada hasilnya atau cuma buat sok-sokan aja biar kelihatan ada kerjaan?”

“Maksud kamu apa?” Soleh mulai panas.

"Gue heran aja kenapa cowok kayak elo yang dipilih sama Menuk..." kata Hendra, kemudian berjalan meninggalkan Soleh. Soleh mendidih karena panas.

"Heh... Cina! Elu pikir tanpa restoran bokap elo, elo bisa hidup? Ngaca, dong!" Hendra berhenti melangkah, ia memutar tubuhnya dan dalam hitungan detik ia melesat kearah Soleh dan melayangkan pukulannya. (Hd?/P/YdA/2011/hlm 256-257)

Hendra bertemu dengan Soleh yang menjadi anggota banser dan sedang mengamankan gereja. Hendra mengejek Soleh dengan menyebut dia satpam. Hendra juga menyinggung mengenai pernikahan Soleh dengan Menuk. Soleh membalas memakinya dengan nada rasis yang membuat Hendra marah. Akhirnya terjadi pertikaian di antara mereka di halaman gereja. 
Belasan orang melangkah cepat ke arah restoran. Di depan kelompok itu, Hendra melihat Soleh. Mereka membawa balok kayu dengan wajah marah.

"Hendra!!!” teriak Soleh dari kejauhan.

Yang terjadi kemudian adalah sebuah kekacauan. Perkelahian yang tidak seimbang. Para pekerja lari keluar restoran karena takut. Para penyerang memukuli apa saja. Kaca-kaca berantakan, pecah dihajar para penyerang. (Hd?/P/YdA/2011/hlm 310)

Provokasi yang dilakukan pemuda ternyata berhasil. Soleh mengikuti ajakan para pemuda untuk menyerang Hendra dan restorannya. Mereka mendatangi restoran tersebut dan merusaknya. Terjadilah pertikaan yang tidak seimbang. Hendra dikeroyok oleh beberapa pemuda dan mereka menghancurkan restoran Koh Tan bahkan sampai membuat Koh Tan meninggal karena pertikaian tersebut.

Berdasarkan kajian teori dan hasil analisis data tentang interaksi sosial masyarakat multikultural dalam novel Harmoni dalam "?” karya Melvy Yendra dan Andriyati berwujud interaksi sosial asosiatif bentuk kerja sama (cooperation) antara atasan dengan bawahan, kerja sama dalam kegiatan keagamaan, dan kerja sama dalam kegiatan kemanusiaan. Akomodasi (accomodation) dalam bentuk toleransi dengan memberi kebebasan dalam menjalankan ibadah, menghormati ajaran dan eksistensi agama lain, kebebasan dalam memeluk agama, dan bebas dalam berpikir. Interaksi sosial disosiatif bentuk persaingan (competition) dalam percintaan. Kontravensi (contravention) dalam bentuk penolakan, memfitnah, provokasi dan intimidasi. pertentangan (conflict) yang terjadi atas dasar rasisme yang mengakibatkan perkelahian, pengerusakan dan jatuhnya korban jiwa 
DAFTAR PUSTAKA

Khasanah, Hidayatul. 2016. Tesis. Nilai Toleransi Dalam Film “?” Karya Hanung Bramantyo (Dalam Perspektif Pendidikan Islam). Institut Agama Islam Negeri (IAIN) Purwokerto.

Lande, Janisa Pascawati. 2014. Tesis. Konstruksi Realitas Konflik Agama dalam Film “?” (Analisis Semiotika). Universitas Hasanuddin Makassar.
Soekanto, Soerjono. 2007. Sosiologi: Suatu Pengantar. Jakarta: PT. Raja Grafindo Persaja.

Yendra, Melvy dan Andriyati. 2011. Harmoni dalam “?”. Jakarta: Mahaka Publishing. 
Lingua Franca: Jurnal Bahasa, Sastra, dan Pengajarannya P-ISSN: 2302-5778 Vol ... No. ... Bulan Tahun Hal ... - ... E-ISSN: 2580-3225 Vol ... No. ... Bulan Tahun Hal ... - ...

\title{
PEDOMAN PENULISAN ARTIKEL JURNAL LINGUA FRANCA (judul artikel, sekitar 15 kata, memberi gambaran penelitian yang telah dilakukan, times new roman 14, bold, spasi 1)
}

\author{
Nama Penulis Pertama, Nama Penulis Kedua, dan seterusnya (nama tanpa gelar \\ dengan huruf Times New Roman 12, Bold, spasi 1) \\ Afiliasi (Universitas atau asal instansi) penulis pertama, kedua, dan seterusnya (jika \\ afiliasi sama, cukup ditulis sekali) \\ Alamat pos-el (Times New Roman 12, spasi 1)
}

ABSTRAK

ABSTRACT

PENDAHULUAN

METODE
Abstrak ditulis dalam bahasa Indonesia dengan panjang maksimal 250 kata berspasi tunggal dengan tipe huruf times new roman 12. Abstrak disertai dengan kata kunci yang terdiri atas maksimal 5 kata. Abstrak memuat uraian singkat tentang masalah dan tujuan penelitian, metode, dan hasil penelitian/simpulan.

Kata Kunci: isi, format, artikel

Abstracts are written in Indonesian with a maximum length of 250 single word with case type of new roman 12. -spaced words. Abstract is accompanied by keywords consisting of a maximum of 5 words. Abstract contains a brief description of the problem and purpose of research, methods, and research results/conclusions.

Keywords: content, format, articles

Pendahuluan berisi latar belakang dan permasalahan penelitian, pemecahan masalah, tujuan penelitian, rangkuman kajian pustaka yang dianggap mewakili dan berkaitan dengan masalah yang diteliti. Isi pendahuluan ditulis dalam satu kesatuan tanpa adanya anak subjudul. Isi pendahuluan diketik dengan 1 spasi, times new roman 12.

Artikel yang lolos akan diterbitkan daring maupun luring oleh pascasasrjana universitas muhammadiyah Surabaya. Aturan rinci format artikel mengikuti ketentuan format artikel pada jurnal tersebut. Format artikel ini menjadi gaya selingkung dari jurnal lingua franca universitas muhammadiyah surabya.

Template untuk format artikel ini dibuat dalam MS Word 2007, dan selanjutnya disimpan dalam format doc. Template ini memungkinkan penulis artikel untuk menyiapkan artikel sesuai dengan aturan secara relatif cepat dan akurat, terutama untuk kebutuhan artikel elektronik yang diunggah ke dalam ejournal Lingua Franca.

Metode ditulis dengan huruf times new roman 12 spasi 1 . Metode berisi penjelasan tentang bagaimana penelitian dilakukan. Pada bagian ini dapat terdiri atas jenis penelitian, model penelitian, populasi dan sampel, teknik pengumpulan data, dan teknik analisis 
PEMBAHASAN

SIMPULAN data. Isi metode ditulis dalam satu kesatuan tanpa adanya anak subjudul.

Pembahasan ditulis dengan huruf times new roman 12 spasi 1. Pembahasan berisi penjabaran mengenai jawaban atau proses pemerolehan jawaban atas rumusan masalah, temuan-temuan yang diperoleh, penjabaran temuan yang dikaitkan dengan teori, dan lain-lain yang dianggap penting, logis, dan relevan.

Dalam penulisan isi pembahasan, diperkenankan menggunakan anak subjudul. Anak subjudul ditulis tanpa nomor dan menggunakan huruf tebal.

Jumlah halaman pembahasan haruslah lebih panjang dari pada pendahuluan.

Simpulan ditulis dengan huruf times new roman 12 spasi 1. Simpulan menyajikan ringkasan dari uraian mengenai pembahasan, mengacu pada rumusan masalah dan tujuan penelitian.

\section{DAFTAR PUSTAKA}

Arikunto, Suharsimi. 2010. Prosedur Penelitian Suatu Pendekatan Praktik. Jakarta: Rineka Cipta.

Depdiknas. 2008. Panduan Pengembangan Bahan Ajar. Jakarta.

Djamarah, Syaiful Bahri dan Aswan Zain. 2010. Strategi Belajar Mengajar. Jakarta: Rineka Cipta.

Eggen, Paul. 2012. Strategi dan Model Pembelajaran. Jakarta: Indeks.

Fenrich, Peter. 2005. Creating Instrucional Multimedia

Solutions: Practical Guidelines for the Real World. California: Informing Science Press.

Budi, Suseno. 2009. Pentingnya Wawasan Kebangsaan dan Bela Negara Bagi Mahasiswa. Surabaya: Mavendra Pers.

Depdiknas. 2006. Kurikulum Tingkat Satuan Pendidikan: Standar Isi. Jakarta.

Ardian, Irawan. 2009. "Manfaat Memahami Implementasi Bela Negara". Dalam Media Pembelajaran. 17 (Februari, X). Surabaya.
Tempo. 2000. "Kedaulatan Rakyat". 11 (Januari, IX). Jakarta.

Wijaya, Kusuma. 2016. "Pentingnya MKU Bermuatan Wawasan Kebangsaan dan Bela Negara Bagi di Perguruan Tinggi". Dalam Jawa Pos. 10 November. Surabaya.

Rahayu. 2016. "Nasionalisme dalam Bahasa dan Sastra Indonesia" Dalam www.onyrahayu.blogspot. com. 30 Maret.

www.onyrahayu.blogspot.com. 2016. "Nasionalisme dalam Bahasa dan Sastra Indonesia”. 30 Maret.

(Daftar pustaka ditulis dengan huruf times new roman spasi 1. Yang dicantumkan dalam daftar pustaka adalah sumber yang dirujuk pada isi artikel. Teknik penulisan daftar pustaka seperti yang dicontohkan di atas) 